\title{
MARY-MICHELLE DECOSTE
}

\section{READING DANTE'S VITA NUOVA}

\begin{abstract}
... the reader of the Vita Nuova is encouraged to uncover the rules of the game, the principles of exclusion and inclusion for the Vita Nuova itself. The critic who tries to solve the libello is responding to a challenge laid down by Dante. ${ }^{1}$
\end{abstract}

Thomas Stillinger

The reader who accepts what Stillinger sees as Dante's challenge faces a difficult task indeed. For, as I will argue below, the rules of this "game" change unexpectedly and are meant to confuse and mislead the reader. As the Vita nuova unfolds, the narrator creates and discards a series of what I will call "model readers" of the text. I will contrast these model readers with the actual reader, who is forced to choose which model he or she most resembles, an identification likely to change a number of times over the course of reading Dante's book. ${ }^{2}$ Thus, the reader never occupies a stable position in relation to the text. The narrator finally loses, however, at his own game. I will argue that Dante's text is in part the story of a narrator who seeks to create authority for himself over his readers, but who ultimately fails and is unable to exercise control over either his reader or his text. ${ }^{3}$ While many critics read Dante and the narrator of the Vita nuova as one, ${ }^{4}$ others sug-

${ }^{1}$ Stillinger, The Song of Troilus, 53.

${ }^{2}$ The actual reader I refer to is the modern reader, although I believe that my argument would apply to the medieval reader as well. For an examination of the medieval reader of Dante, see Noakes, Timely Reading.

${ }^{3}$ Noakes locates Dante's realization of a lack of authorial control in the Commedia rarher than in the Vita nuova: "According to Dante at this time [of the writing of the Vita nuova], the poet is responsible for making sure readers understand what lies beneath the surface of words and do not fall into traps of misinterpretation. Only later (as illustrated in the Paolo and Francesca episode) does he come to realize that such protection of the reader exceeds the author's powers." Timely Reading, 76.

${ }^{4}$ See, for example, Ahern, "The Reader on the Piazza" and, to a lesser extent, Stillinger. 
gest a split between the two. Vincent Moleta, for example, refers to the "author-persona now calling up and ordering the experience of his past," 5 and Domenico De Robertis writes that "la funzione dell'autore è quella secondaria ... dello 'scriba." 6 I would like to use this idea of an "authorpersona," that is, of a persona who conforms imperfectly to the author, in order to read the narrator as a character created by Dante, or at least as a younger Dante with whom the author of the Vita nuova does not entirely identify. I will argue below that Dante uses this narrator and the narrator's confusion (confusion both created by and used against the narrator) to alert his audience to the complexity of reading, the shortcomings of language, and the dynamic relationship between author and audience. ${ }^{7}$

In the Vita muova's incipit, the narrator immediately puts the reader in a subordinate position:

In quella parte del libro de la mia memoria dinanzi a la quale poco si potrebbe leggere si trova una rubrica la quale dice: Incipit vita nova . Sotto la quale rubrica io trovo scritte le parole le quali è mio intendimento d'assemplare in questo libello e se non tutte, almeno la loro sentenzia. $(I, 1)^{8}$

Robert Pogue Harrison describes how time has revealed to the narrator that which the protagonist and the reader have yet to learn: "Sentenzia here means the principle of narrative coherence that orders the temporal mass of the past and places its events on a linear and teleological trajectory. [...] A past event receives its meaning from the outcome it contributes

\section{Moleta, "Forward," 3.}

'De Robertis, “'Incipit vita nova' (V.N., I)," 12.

${ }^{7} \mathrm{My}$ argument here is nearly the opposite of what Noakes claims in her "Hermeneutics, Politics, and Civic Ideology in the Vita Nuova." According to Noakes, "the reader, if not already possessed of the narrator's superior hermeneutic skills, may at least expect to acquire them in the course of reading what is in any case just a short book. Both the narrator and the reader will then occupy together a special position: they will be an elite, constituted on the basis of hermeneutic qualifications" (46). Robin Kirkpatrick prefers the word "cell" to Noakes' "elite" in "Dante's Beatrice and the Politics of Singularity." I will resist what Robert Pogue Harrison, in The Body of Beatrice, calls the "almost irresistible compulsion to read [the Vita nuova] against the background of Dante's later works, above all the Commedia" (151) and leave comparison with the episode of Paolo and Francesca aside.

8 All quotations from the Vita nuova are from the edition of the Biblioteca Universale Rizzoli (Milan, 1984), a reproduction of Michele Barbi's 1932 edition. 
to bring about." Without disagreeing with Harrison, I want to focus here on the effect the narrator's superior position has on the reader, who must ask, Who is the narrator, the "io" speaking here? Without this information, the reader cannot yet know how to position him or herself in relation to the narrator. Nor does the narrator specify who wrote either the words that he discovered or the rubric under which they appear; the author's agency is absent. And what is the "poco" that appears before "Incipit vita nuova"? The reader must accept the narrator's assessment that it is not important. Furthermore, the narrator has taken it upon himself "d'assemplare" the words he finds written, "e se non tutte, almeno la loro sentenzia." If assemplare is taken to mean copiare, the reader understands that the narrator has access to an original text that it is his job to reproduce faithfully. ${ }^{10}$ The narrator thus acts as an intermediary between the author of the words and those who will read them. Yet, copyists frequently make mistakes or may edit or censor material, and the reader has no opportunity to check the copy against the original. Furthermore, an imitation always differs at least slightly from its model, so if assemplare is taken to mean imitare, the reader is aware that an imperfect copy is being produced. In any case, the narrator has a privileged position in relation to the author of the "libro de la mia memoria," a position the reader does not enjoy. The narrator is the first model reader presented in the Vita nuova, and he is a difficult one to imitate because the relationship between words and their meaning, the "sentenzia," is already clear to him. The reader can be sure that the narrator's interference will be felt, since the narrator admits that he will not copy all the words, but he will at least relay their general sense. The actual reader is thus in a rather precarious position; with no access to the original text, he or she must rely on the judgment of the narrator, who has yet to prove himself trustworthy.

The narrator is quick to exploit his prerogative not only just to relay

${ }^{9}$ Harrison, The Body of Beatrice, 140. I will follow Harrison's distinction between the narrator and the protagonist of the Vita nuova, the narrator being the one who speaks in the present tense, recalling events from the past, and the protagonist being the one experiencing events as the narrator describes them. Because these two characters become conflated at various points throughout the book, this distinction can be difficult to maintain; I use it only to distinguish between the one who is looking back from a position of superior knowledge and the one who is looking ahead. These two characters converge definitively at the end.

${ }^{10}$ Battaglia defines assemplare as follows: "1. fare una cosa sull'esempio di un'altra; copiare, ritrarre da un esemplare; rappresentare, riprodurre; imitare 2. trascrivere da un testo originale, mettere in copia." ad vocem. 
the meaning of words rather than to reproduce them, but also to delete things altogether. In the next chapter, after describing the first time he saw Beatrice, the narrator says " $E$ però che soprastare a le passioni e atti di tanta gioventudine pare alcuno parlare fabuloso, mi partirò da esse, e trapassando molte cose le quali si potrebbero trarre de l'essemplo onde nascono queste, verrò a quelle parole le quali sono scritte ne la mia memoria sotto maggiori paragrafi" (II, 10). Having already asserted his superior skills in reading, the narrator here asserts his superior skills of judgment: he is able to tell the difference between maggiore and minore. It is on this basis that he decides what material to include in the "libello" and what material to exclude. Again, the author of the words the narrator finds written in the book of his memory remains anonymous; if the narrator himself wrote them, he does not say so. The reader, who has no access to the censored material, never has the opportunity to develop skills of judgment and must once again rely on the narrator to determine what is worthwhile.

As he describes his first vision, the protagonist joins the narrator in demanding trust from his reader without having earned it. After being greeted by his lady for the first time, the protagonist returns to his room where he falls asleep. He has a vision in which Love appears to him, holding Beatrice in his arms and the protagonist's heart in one of his hands. Love awakens the sleeping lady and makes her eat the heart while the protagonist looks on. Then Love and Beatrice ascend into heaven. In this whole passage, what appears and what only seems to appear are confounded by the repetition of the verbs "apparare" and "appare": "l'apparimento," "apparve," "parve," (III, 1) "apparve," "parea," "parea," (III, 3) "parea," "parea," (III, 4) "parea," "parea," (III, 5) "parea," (III, 6) "parea," (III, 7) "apparita," "appare," (III, 8) "apparuto" (III, 9). The reader cannot know what the protagonist actually saw and what he only thinks he saw, and thus is not sure what to believe.

After awakening, the protagonist decides to make his vision known:

Pensando io a ciò che m'era apparuto, propuosi di farlo sentire a molti li quali erano famosi trovatori in quello tempo: e con ciò fosse cosa che io avesse già veduto per me medesimo l'arte del dire parole per rima, propuosi di fare uno sonetto, ne lo quale io salutasse tutti li fedeli d'Amore e pregandoli che giudicassero la mia visione, scrissi a loro ciò che io aveva nel mio sonno veduto. (III, 9)

The poem that follows marks the protagonist's poetic debut. He introduces it with some pride ("io avesse già veduto per me medesimo l'arte del dire parole per rima" [italics mine]) and almost as a challenge to his audience ("pregandoli che giudicassero"). Two groups are called upon as read- 
ers of this poem: the "famosi trovatori," to whom the poem is addressed, and "ciascun'alma presa e gentil core," who are addressed within the poem. I would like to propose a third group of possible readers: the "molti" introduced earlier in the narrative who have an imperfect understanding of the relationship between the narrator's lady, "la quale fu chiamata da molti Beatrice li quali non sapeano che si chiamare" (II, 1), and her name. These "molti" are recalled in the description of the poets ("molti li quali erano famosi trovatori"), and they are the ones who respond to the narrator's request: "A questo sonetto fue risposto da molti" (III, 14). The address of the poem raises the question: who are these loving souls? Are they the "molti" or the "famosi trovatori?" Or both? Or neither?

Indeed, no one, the narrator says, was a successful reader of the poem at first: "Lo verace giudicio del detto sogno non fue veduto allora per alcuno, ma ora è manifestissimo a li più semplici" (III, 15). Even Cavalcanti, whose friendship the protagonist dates from this exchange of sonnets, fails to determine "lo verace giudicio." Susan Noakes assumes that readers will, in fact, one day be able to interpret the vision: "Dreams are like Beatrice's name: their meaning can be understood only later. Deferral is inherent to their interpretation. The hope can thus always be maintained that even the simplest reader will eventually understand them." 11 At the same time, she suggests that it is possible to read these words as ironic:

There is irony in Dante's assertion that, ord, just anyone can see exactly what his dream means. Even the few allusions discussed here make evident that its meaning is by no means "manifestissimo." "Ora" cannot mean only "now" after [Beatrice's] death; it also means "now" that Dante has written his commentary, "now" that he has shown the dimensions of the hermeneutic expansion of which his apparently conventional love story is capable. The last line of chapter III challenges those of its readers who are not "li più semplici," and certainly the trovatori, to look out in this libello for what does not at first meet the eye. ${ }^{12}$

It is indeed impossible for the protagonist's vision ever to be "manifestissimo;" as Noakes shows, it is full of Biblical references and dense Christian imagery. ${ }^{13}$ I propose that through exaggeration ("manifest issimo a li piu semplici"), the narrator is instead suggesting that the meaning of

${ }^{11}$ Noakes "Hermeneutics, Politics, and Civic Ideology in the Vita Nuova," 49. ${ }^{12}$ Noakes "Hermeneutics, Politics, and Civic Ideology in the Vita Nuova," 51. ${ }^{13}$ See Noakes "Hermeneutics, Politics, and Civic Ideology in the Vita Nuova," 50-51. 
the vision will never be clear, and the narrator will not clarify it. ${ }^{14}$ Indeed, the protagonist's broadcasting of his vision has further obscured the vision by inviting various differing interpretations ("fue risposto da molti e di diverse sentenzie" [italics mine]). These readings constitute an interpretive veil that becomes part of the vision's public manifestation. The vision is no longer just a vision; it has also become a text, complete with critical commentary. Called upon to read the protagonist's vision, the reader is then told that it is now already quite clear. The narrator does not, however, give readers any clues about how to read this text, implicitly accusing anyone who cannot understand it of being a worse reader than even "li più semplici."

These "molti" appear again in the form of the "molti amici" (IV, 1) who become concerned about the apparently weakened protagonist. Another group of "molti" is jealous, and wants to know what is the matter with him. He admits that it is Love, because he cannot conceal the physical signs on his face ("Dicea d'Amore, però che io portava nel viso tante de le sue insegne, che questo non si potea ricovrire" [IV, 2]). However, language, or in this case the withholding of language, allows him to maintain his secret and to encourage the confusion of his audience: "E quando mi domandavano 'Per cui t'ha così distrutto questo Amore?,' ed io sorridendo li guardava, e nulla dicea loro" (IV, 3). The physical signs are irrefutable, but by controlling language, the protagonist can control the perception of the "molti."

Nowhere is the protagonist's manipulation seen more clearly than in the case of the "donna schermo." This woman happened to be sitting directly between the protagonist and Beatrice, so that while he gazed upon his beloved, it appeared that he was really looking at the other woman. The woman looked back at him, and "molti s'accorsero de lo suo mirare" (V, 2). Taking note of this, the protagonist seizes the opportunity to deceive those who might suspect that his love is for Beatrice:

F. mantenente pensai di fare di questa gentile donna schermo de la veritade, e tanto ne mostrai in poco tempo, che lo mio secreto fue creduto sapere da le più persone che di me ragionavano. Con questa donna mi celai alquanti anni e mesi; e per più fare credente altrui, feci per lei certe cosette per rima, le quali non è mio intendimento di scrivere qui, se non in quanto facesse a trattare di quella gentilissima Beatrice; e però le lascerò tutte, salvo che alcuna cosa ne scriverò che pare che sia loda di lei. $(\mathrm{V}, 3)$

${ }^{14}$ Harrison writes of III, 15, "By making such a declaration and yet refusing to disclose the dream's "true meaning" for his reader, Dante seems deliberately to have preserved for us the dream's most essential quality, namely, its hermeneutic provocation." Harrison, "Mi parea vedere una persona dormire nuda," 24. 
Here, the protagonist assures the reader of the Vita nuova that there is an absolute truth ("la veritade") of which he or she is aware: the protagonist is in love with Beatrice. The reader is therefore in a position epistemologically superior to that of "le più persone;" they believe that the protagonist is in love with the "donna schermo." Thus, the reader can look with scorn upon those who do not read the situation carefully enough. Yet this position of knowledge that the protagonist has invited the reader to share is ultimately not tenable. The protagonist quickly reminds the reader that the protagonist knows more by mentioning "certe cosette," which he does not subsequently share. That which he agrees to write "pare che sia loda di lei," that is, of Beatrice. "Seems" to whom? To the protagonist? To the reader? To Beatrice herself? The reader's position of authority over other readers is again destabilized as the protagonist reasserts his superiority.

The protagonist further mistreats the reader in the seventh chapter. When the "donna schermo" leaves for a distant town, the protagonist decides to write something for the occasion:

E pensando che se de la sua partita io non parlasse alquanto dolorosamente, le persone sarebbero accorte più tosto de lo mio nascondere, propuosi di farne alcuna lamentanza in uno sonetto; lo quale io scriverò, acciò che la mia donna fue immediata cagione di certe parole che ne lo sonetto sono sì come appare a chi lo intende. (VII, 2)

Again the protagonist professes his intent to deceive those who are poor readers while claiming to reserve understanding for an elite reader or group of readers. This time, the position of the seemingly elite actual reader is threatened not by the protagonist reasserting his authority, but by a model reader. When the "donna schermo" was first introduced, the reader of the Vita nuova was aware of his or her position of superior knowledge. In this second case, the protagonist suggests that anyone who understands the sonnet ("chi lo intende"), without prior knowledge of the protagonist's love for Beatrice, might come to understand that this other woman functions only as a screen. The content of the poem suggests how this knowledge might be obtained:

O voi che per la via d'Amor passate, attendete e guardate

s'elli è dolore alcun, quanto è 'l mio, grave;

e prego sol ch' audir mi sofferiate,

e poi imaginate

s'io son d'ogni tormento ostale e chiave. (VII, 3) [italics mine]

Thus, through careful attention, the model reader proposed by the protagonist here might obtain understanding of the true meaning behind the poem. The actual reader of the Vita nuova is therefore forced to recog- 
nize that the exclusivity of the position of knowledge that he or she occupies is threatened by the keen model reader the protagonist proposes.

The poem itself is a meditation on the reader's position:
Or ho perduta tutta mia baldanza
che si movea d'amoroso tesoro,
ond'io pover dimoro,
in guisa che di dir mi ven dottanza.
Si che volendo far come coloro
che per vergogna celan lor mancanza,
di fuor mostro allegranza,
e dentro da lo core struggo e ploro. (VII, 5-6)

The love that once spurred poetic creation is gone, so now instead of writing comes fear. Yet it comes not just instead of, but disguised as ("in guisa che di") writing, so that it is no longer love but fear that is the source of poetry. The poet implies that this writing that stems from fear is not really writing; it is only something disguised as writing. However, anxious to hide his sadness, the poet puts on a happy face. If both disguises are successful, that is, if the poet convinces others that he is happy, and if he can pass off fear's disguise as real writing, who is to know the difference? The reader, who up until this point has been denied the possibility of developing any critical skills, will be unable to recognize the poet's deception. The poem describes an uncomfortable relationship between the poet and his audience in which the poet has the power and the desire to deceive his unsophisticated readers.

The god of Love himself, who inspires poetry, teaches skills of deception to the protagonist. In the ninth chapter, the protagonist imagines Love as a pilgrim who informs him that another woman will take the place of the "donna schermo." He also admonishes the protagonist to keep this information a secret: "Ma tuttavia, di queste parole ch'io tho ragionate se alcuna cosa ne dicessi, dille nel modo che per Joro non si discernesse lo simulato amore che tu hai mostrato a questa e che ti converrà mostrare ad altri" (IX, 6). Here, Love instructs the protagonist to use speech to deceive. The reader, then, must be extremely careful in reading the prose sections of the Vita mova. The prose explications, which the narrator will later insist are meant to clarify the meaning of the poems, have instead the potential to be deceptive.

The deceit in which Love instructs the protagonist has an unintended consequence: tongues wag, and their "soverchievole voce che parea che m'infamasse viziosamente" (X, 1) causes Beatrice to deny the protagonist her greeting. I would like to argue that this is a turning point in the nar- 
rative. Prior to this moment, the narrator and the protagonist have presented themselves as in control of language and therefore of their deceptions. From this moment on, the narrator and the protagonist show themselves as struggling, mostly unsuccessfully, to regain control. This struggle takes place on two fronts. On the one hand, the narrator and the protagonist attempt further to manipulate the reader in ways upon which I shall elaborate below; on the other hand, the narrator tries to work out the relationship between the prose and the poetry of the libello. What he finds is that the former does not necessarily serve the latter, and that he cannot fully control the way the reader compares the two.

Love himself is a deceptive narrator and contributes to the protagonist's confusion. He appears again to the protagonist in a vision and tells him: "Fili mi, tempus est ut pretermicantur simulacra nostra" (XII, 3). The use here of nostra rather than tua indicates the complicity of Love in deceit. At this point, Love breaks into tears; when the protagonist asks him why, Love answers, "Ego tanquam centrum circuli, cui simili modo se habent circumferentie partes; tu autem non sic" (XII, 4). The protagonist questions him further: "Che è ciò, segnore, che mi parli con tanta oscuritade?" (XII, 5). Love replies, this time in Italian: "Non dimandare più che utile ti sia"(XII, 5). The protagonist here shows himself to be an unsuccessful reader, vulnerable to the whims of a superior narrator (Love), just as the narrator's and protagonist's readers are vulnerable.

Why, indeed, does Love speak in such a confusing manner? Charles Singleton postulates: "Love's words are like the number nine and the sign of the true meaning in connection with the first vision: it takes the actual death of Beatrice to make them meaningful as signs and utterances. They are prophetic of her death." 15 It is impossible, then, for the protagonist to understand these words as they are spoken by Love; their meaning is to be revealed later. If Singleton is right, and the protagonist must wait to understand Love's words, might the reader of the Vita nuova also be expected to wait for a deferred meaning? As to why Love speaks in Latin, Singleton writes:

The shift from Latin to the vernacular on the part of the God of Love when he utters these last words is in itself a part of the total revelation made by the vision. For only the words in Latin are of the nature of oracle, and by being put in that language they are set apart and raised to a proper dignity. When Love changes to Italian one feels that somehow he has stepped down to the level of the poet and of everyday affairs. Thus, like the number nine, the Latin too is a sign. ${ }^{16}$

15 Singleton, An Essay on the Vita muova, 16.
${ }^{16}$ Singleton, An Essay on the Vita muova, 17. 
This explanation seems to me unsatisfactory, in light of a comment made by the narrator later in the work. In explaining why he does not complete a quotation from the prophet Jeremiah, which he begins in Latin, he writes,

E se alcuno volesse me riprendere di ciò, ch'io non scrivo qui le parole che seguitano a quelle allegate, escusomene, però che lo intendimento mio non fue dal principio di scrivere altro che per volgare; onde, con ciò sia cosa che le parole che seguitano a quelle che sono allegate, siano turte latine, sarebbe fuori del mio intendimento se le scrivessi. (XXX, 2)

Why, then does the narrator deem it inappropriate to quote Jeremiah, but appropriate to quote Love in Latin? It seems particularly strange since the narrator insists that vernacular is the language of love:

E lo primo che cominciò a dire sì come poeta volgare, si mosse però che volle fare intendere le sue parole a donna, a la quale era malagevole d'intendere li versi latini. E questo è contra coloro che rimano sopra altra matera che amorosa, con ciò sia cosa che cotale modo di parlare fosse dal principio trovato per dire d'amore. $(\mathrm{XXV}, 6)$

Italian, as opposed to Latin, is thus used to make things clearer to those who have difficulty in understanding. If vernacular is the language most fit to express matters pertaining to love, why does Love speak to the protagonist in Latin?

Verses of love have been used by the protagonist to deceive, first with the "donna schermo" and then with her replacement. Love commanded him to hide his real purpose behind words. Now, Love is doing the same to the protagonist. It does not matter that the protagonist understands Latin. By failing to use the language whose purpose it is to clarify matters pertaining to love, Love tells the protagonist to address Beatrice only in a round-about way: "Queste parole fa che siano quasi un mezzo, sì che tu non parli a lei immediatamente, che non è degno" (XII, 8). Yet at the same time, the words of the protagonist are meant to clarify Beatrice's mistaken belief about him, namely that he was harming the second "donna schermo." Love commands the protagonist:

voglio che tu dichi certe parole per rima, ne li quali tu comprendi la forza che io tengo sopra te per lei; e come tu fosti suo tostamente da la tua puerizia. E di ciò chiama testimonio colui che lo sa, e come tu prieghi lui che li le dica; ed io, che son quelli, volentieri le ne ragionerò, e per questo sentirà ella la tua volontade, la quale sentendo, conoscerà le parole de li ingannati. (XII, 7) 
The interesting thing to note here is that the poetry, rather than clarifying anything, still must be explained by Love before it will be clear to Beatrice. Thus the reader of the Vita nuova and the protagonist, the "reader" of Love's discourse, are both asked to accept deceit and deferred meaning as conditions of reading. Beatrice, in this passage, is the privileged reader. She will understand the protagonist's true feeling (the strength and the exclusivity of this understanding emphasized by both the pronoun "ella" following the verb "sentirà" and the repetition of the verb ["sentirà," "sentendo"]), and with this understanding, she will recognize ("conoscerà") the liars' words. With this, the truth about the protagonist, which at first was only partly ("alquanto" [XII, 7]) known to Beatrice, is clarified for her.

To those readers who don't understand the ballad that follows, the narrator says:

Potrebbe già l'uomo oppore contra me e dicere che non sapesse a cui fosse lo mio parlare in seconda persona, però che la ballata non è altro che queste parole ched io parlo: e però dico che questo dubbio io lo intendo solvere e dichiarare in questo libello ancora in parte più dubbiosa, e allora intenda qui chi qui dubita, o chi qui volesse opporre in questo modo. (XII, 17)

Surely the narrator will not explain this poem in a section of his book that is not only more confusing, but that is also to be presented at an unspecified future time. The narrator's stated intent to "solvere $\mathrm{e}$ dichiarare" must thus be considered forever deferred. Moreover, the narrator is quite aggressive in his refusal to help the reader at this point, using the imperative ("intenda qui") and hard-sounding monosyllables ("intenda qui chi qui dubita, o chi qui volesse opporre" [emphasis mine]) as he draws a parallel between the reader who does not understand the poem ("chi dubita") and the reader who objects to it ("chi volesse oppore"). The unskilled reader is thus made to feel like a belligerent reader, who, unlike Beatrice, has no one to explain the meaning of the poem.

In chapter fourteen, the narrator again attacks the unskilled reader, or the reader whom the narrator considers to be in opposition to his project in some way. After presenting a sonnet, the narrator writes:

Questo sonetto non divido in parti, però che la divisione non si fa se non per aprire la sentenzia de la cosa divisa; onde con ciò sia cosa che per la sua ragionata cagione assai sia manifesto, non ha mestiere di divisione. Vero è che tra le parole dove si manifesta la cagione di questo sonetto, si scrivono dubbiose parole, cioè quando dico che Amore uccide tutti li miei spiriti, e li visivi rimangono in vita, salvo che fuori de li strumenti loro. E questo dubbio è impossibile a solvere a chi non fosse in simile 
grado fedele d'Amore; e a coloro che vi sono è manifesto ciò che solverebbe le dubitose parole: e però non è bene a me di dichiarare cotale dubitazione, acciò che lo mio parlare dichiarando sarebbe indarno, o vero di soperchio. (XIV, 13-14)

Here the narrator posits two model readers: one who is a follower of Love and one who is not. He admits of possible trouble spots in interpreting the poem, but then expresses his resolve not to clarify them, since for followers of Love, his words should be clear, and to those who do not follow Love, it is impossible that his words will ever be clear. The reader must choose which model he or she most closely resembles. The narrator does not admit a third possible reader, that is, one who is a follower of Love but who still does not understand the poem. This reader would be forced to doubt the degree of his or her fidelity to Love. To such a reader, explanation would not be "indarno," but no explanation is forthcoming. Nor does the narrator specify why confusion on the part of the reader would be "impossibile a solvere." From what the narrator says, it would seem that this should be the job of the prose sections, that is, "per aprire la sentenzia de la cosa divisa." As Singleton writes, "The intention and substance of a pocm, that part of a poem which reason can use, is conceived of as being on the inside of a poem (intus), and a division serves to "open up" the poem so that reason may lay hold of that substance." 17 However, in this section, reason is completely left out of the equation. The only readers who are able to understand the poem are those who meet certain qualifications prior to their reading of it, that is, those who are followers of Love. The reader of the Vita nuova who is not a follower of Love, or who is unable to understand the poem, is therefore denied the chance to use his or her reason in order to gain understanding. This reader is ultimately unable to position him or herself in relation to the poem, in relation to the model readers that the narrator proposes, and is thus alienated from any reading of the book. In chapters twelve and fourteen, then, the narrator proposes that reading is not for everyone; some readers (unskilled readers, belligerent readers) will never understand.

The narrator returns to the possibility of misunderstanding in chapter nineteen. After the canzone Donne chiavete intelletto d'amore, he expresses his intention to divide the poem more carefully than others "acciò che sia meglio intesa" (XIX, 15). The narrator himself, however, seems to doubt that this can be accomplished. When listing the attributes of his beloved, he comes eventually to her mouth: "dico de la bocca, la quale è fine

\footnotetext{
17Singleton, An Essay on the Vita mova, 47.
} 
d'amore. E acciò che quinci si lievi ogni vizioso pensiero, ricordisi chi ci legge, che di sopra è scritto che lo saluto di questa donna, lo quale era de le operazioni de la bocca sua, fue fine de li miei desiderii mentre ch' io lo potei ricevere" (XIX, 20). It is as if the narrator thinks that through his exegesis the reader has somehow gotten the wrong idea about the poet's intentions. Why does the narrator choose this moment to talk about any "vizioso pensiero" that a reader may or may not have? It is as though the thought suddenly occurs to him that his words may be misunderstood and he is trying to anticipate any inappropriate thoughts his readers may have.

Despite this, the narrator insists that he could have made even more extensive divisions:

Dico bene che, a più aprire lo intendimento di questa canzone, si converrebbe usare di più minute divisioni; ma tuttavia chi non è di tanto ingegno che per queste che sono fatte la possa intendere, a me non dispiace se la mi lascia stare, ché certo io temo d'avere a troppi comunicato lo suo intendimento pur per queste divisioni che fatte sono, s'elli avvenisse che molti le potessero audire. (XIX, 22)

$\mathrm{He}$ is insisting that his exegesis is so powerful that it is sure to work; even those who should not be able to understand the poetry are able to understand it by virtue of the exegesis. He furthermore proposes that the smaller the divisions, the clearer the meaning, suggesting that if he were to continue in his explanation, the meaning would become clear to everyone. This contrasts sharply both with his prior insistence that it is sometimes impossible to open the meaning of a poem and with his fear of being misunderstood.

In chapter twenty-five, the narrator suggests a reader quite different from the one who was encouraged to "lasciare stare" (XIX, 22) poetry that he or she did not understand. This reader is "degna da dichiararle onne dubitazione" (XXV, 1). He proposes that this reader might be confused by the fact that the poet speaks "d'Amore come se fosse una cosa per sé, e non solamente sustanzia intelligente, ma sì come fosse sustanzia corporale" $(\mathrm{XXV}, 1)$. He then proposes to clear up this matter, "secondo che è buono a presente" $(\mathrm{XXV}, 3)$. He explains that "Amore non è per sé sì come sustanzia, ma è uno accidente in sustanzia" (XXV, 1), although it is true that the poet speaks of him as though he had a body. He justifies himself by saying that he is using only the poetic license that is suitable for him, and since greater license is given to writers of poetry than to writers of prose in Latin, the same thing should be granted to writers of poetry in Italian. Thus, "se alcuna figura o colore rettorico è conceduto a li poete, conceduto è a li rimatori" (XXV, 7). This poetic license is not to be abused, however: "degno è lo 
dicitore per rima di fare lo somigliante, ma non sanza ragione alcuna, ma con ragione la quale poi sia possibile d'aprire per prosa" (XXV, 8).

Here, the narrator suggests that there is meaning within the poem that is decorated by rhetorical figures. This meaning can be subsequently revealed by prose. Thus, the narrator proposes a schism between the functions and the purposes of poetry and prose: poetry hides or obscures meaning, prose reveals it. He warns potential writers a second time that there must be a purpose for using rhetorical devices:

E acciò che non ne pigli alcuna baldanza persona grossa, dico che né li poete parlavano così sanza ragione, né quelli che rimano deono parlare così non avendo alcuno ragionamento in loro di quello che dicono; però che grande vergogna sarebbe a colui che rimasse cose sotto vesta di figura o di colore rettorico, e poscia, domandato, non sapesse denudare le sue parole da cotale vesta, in guisa che avessero verace intendimento. (XXV, 10)

In this passage the narrator agains refers to true meaning hidden under rhetorical devices and insists that the poet be able to reveal that meaning, by means of prose, upon demand. He has already, however, shown his own inability to do this in chapter fourteen, where he admits that the reader's confusion is sometimes "impossibile a solvere." I believe that the prose section of chapter twenty-five must be read with this in mind. It then becomes an ironic suggestion that it is not always possible (or even desirable) to remove the veil of rhetoric from poetry, that perhaps even the poet himself does not know what he will find there. ${ }^{18}$

After the death of Beatrice, the narrator further explores the relationship between poetry and prose by radically changing the way in which he positions the prose sections in relation to the poetry: "E acciò che questa canzone paia rimanere più vedova dopo lo suo fine, la dividerò primo che io la scriva; e cotale modo terrò da qui innanzi" (XXXI, 2). If the death of Beatrice allows the reader (and the protagonist) to understand certain things that had previously been obscure (for example, Love's mysterious words in Latin and the meaning of the number nine), it does not seem to allow for a deeper understanding of the poems. Prose following poetry served, at least in theory, to educate the reader, who had the opportunity

${ }^{18} \mathrm{My}$ conclusions here are different from those of Stillinger, who writes that the divisioni are tools "for imperfect readers [that] work to overcome dividedness. Likewise the narrative prose-sequential, circumstantial-is inferior to the relatively atemporal, relatively abstract lyrics, but its function is to serve them beneficially, to "aprir per prosa" (25.8) [open through prose] that which might remain inaccessible otherwise" Stillinger, The Song of Troilus, 83. 
first to read the poem and then to reflect upon what it might mean. The reader could subsequently look to the prose for an explanation of any ideas that were not clear. When the prose exegesis precedes the poem, the reader does not have the chance to do any work. The reader knows what the narrator thinks about the poem before he or she even reads it. ${ }^{19}$

The way in which the anteriority of the prose section influences the reader's interpretation of the poem is illustrated in chapter thirty-three. The protagonist describes a poem written for a man believed to be Beatrice's brother:

E però anzi ch'io li dessi questo soprascritto sonetto, sì dissi due stanzie d'una canzone, l'una per costui veracemente, e l'altra per me, avvenga che paia l'una e l'altra per una persona detta, a chi non guarda sottilmente, ma chi sottilmente le mira vede bene che diverse persone parlano, acciò che l'una non chiama sua donna costei, e l'altra sì, come appare manifestamente. Questa canzone e questo soprascritto sonetto li diedi, dicendo io lui che per lui solo fatto l'avea. (XXXIII, 2-3)

Because the reader already knows that two people are talking in the poem, he or she approaches the poem with knowledge superior to that of the person for whom it was written. Yet this approach also makes it more difficult for the reader to disagree with the narrator's interpretation of the poem. When the prose follows the poem, the reader has a chance to form his or her own ideas about the poem before proceeding to the prose section. The narrator's exegesis is then read against the ideas that the reader has already developed. When the prose precedes the poem, however, the reader reads the poem with the narrator's ideas in mind and thus has less room to draw different conclusions.

When the language in a poem and in its exegesis is very similar, the reader wonders what the efficacy is of having both. For example, the canzone Donna pietosa e di novella etate, presented in chapter twenty-three, echoes the language used in the preceding prose section. Much of the same information is relayed: "Di necessitade convene che la gentilissima Beatrice alcuna volta si muoia" (XXIII, 3) in the prose section becomes "Ben converrà che la mia donna mora" (XXIII, 21) in the canzone. The friend who says, "Or non sai? la tua mirabile donna è partita di questo secolo?" (XXIII, 6) in the prose section asks "Che fai? non sai novella? / morta è la donna tua, ch'era si bella" in the canzone. The question then becomes whether or not the poem can replace the prose, or vice versa.

${ }^{19} \mathrm{My}$ argument here is similar to that made by Steven Botterill in "Però che la divisione non si fa," 72 . 
The prose section that precedes the canzone in chapter twenty-three is written, as are most of the prose sections, in a historical register: the protagonist appears to relate events exactly as they happened. He continues in this purported veracity when he tells the story of his vision to the women assembled around him: "Io vi diroe quello ch'i' hoe avuto.' Allora, cominciandomi dal principio infino a la fine, dissi loro quello che veduto avea, tacendo lo nome di questa gentilissima" (XXIII, 15). Yet already in this historical account, posing as the truth told "from beginning to end," there is a hint of censorship: the protagonist omits the name of his betoved. Although the act of poetic creation reshapes history and gives it a new form, it is not necessarity less truthful than its prose account. Prose and poetry are equally unreliable.

The inadequacy of his linguistic skills is what leads the protagonist to fall ultimately silent after receiving a vision: "Appresso questo sonetto apparve a me una mirabile visione, ne la quale io vidi cose che mi fecero proporre di non dire più di questa benedetta infino a tanto che io potesse più degnamente trattare di lei" (XLII, 1). This project is deferred to some unspecified future date: "Sì che, se piacere sarà di colui a cui tutte le cose vivono, che la mia vita duri per alquanti anni, io spero di dicer di lei quello che mai non fue detto d'alcuna" (XLII, 2). This is the last of a number of deferrals in the libello. The narrator has for the moment given up in his attempt to control langauge. The reader, rather than learning interpretive skills, has learned instead of his own hermeneutic shortcomings. As Harrison writes, "what does the 'story' dramatize if not a series of corrections and revisions in the poet's search for an adequate idiom?" The narrator and the protagonist, who throughout the text tried to show themselves masters of language but were ultimately unable to find this idiom, ${ }^{20}$ become the final model for the reader. The narrator-protagonist, now one, assures the reader, "studio quanto posso" (XLII, 2) in the effort to create a new idiom ("quello che mai non fue detto") that may prove more reliable, and the reader must do likewise in the struggle to create and understand meaning made with words.

University of Guelph

\section{WORKS CITED}

Ahern, John. "The Reader on the Piazza: Verhal Duels in Dante's Vita nuova." Texas Studies in Literature and Language 32.1 (Spring 1990): 18-39.

${ }^{20}$ Harrison, The Body of Beatrice, 150. 
Alighieri, Dante. Vita nuova. Ed. Michele Barbi. Milano: Biblioteca Universale Rizzoli, 1984.

Battaglia, Salvatore. Il grande dizionario della lingua italiana. Torino: Unione tipografico-editrice torinese, 1961-2002.

Botterill, Steven. "Però che la divisione non si fa se non per aprire la sentenzia de la cosa divisa (V.N., XIV, 13): The "Vita nuova" as Commentary"pp. 61-76 in La gloriosa donna de la mente. Ed. Vincent Moleta. Florence: Leo S. Olschki, 1994.

De Robertis, Domenico. "Incipit vita nova' (V.N., I): Poetica del (ri)cominciamento." pp. 11-19 in La gloriosa donna de la mente. Ed. Vincent Moleta. Florence: Leo S. Olschki, 1994.

Harrison, Robert Pogue. The Body of Beatrice. Baltimore: Johns Hopkins University Press, 1988.

—. "Mi parea vedere una persona dormire nuda' (V.N., III, 4): The body of Beatrice." pp. 21-35 in La gloriosa donna de la mente. Ed. Vincent Moleta. Florence: Leo S. Olschki, 1994.

Kirkpatrick, Robin. "Dante's Beatrice and the Politics of Singularity." Texas Studies in Literature and Language 32.1 (Spring 1990): 101-119.

Moleta, Vincent. "Forward"pp. 1-10 in La gloriosa donna de la mente. Ed. Vincent Moleta. Florence: Leo S. Olschki, 1994.

Noakes, Susan. "Hermeneutics, Politics, and Civic Ideology in the Vita muova: Thoughts Preliminary to an Interpretation." Texas Studies in Literature and Language 32.1 (Spring 1990): 40-59.

_. Timely Reading: Between Exegesis and Interpretation. Ithaca, NY: Cornell University Press, 1988.

Singleton, Charles. An Essay on the Vita nuova. Cambridge, MA: Harvard University Press, 1958.

Stillinger, Thomas C. The Song of Troilus: Lyric Authority in the Medieval Book. Philadelphia: University of Pennsylvania Press, 1992. 